\title{
IODP Expedition 334: An Investigation of the Sedimentary Record, Fluid Flow and State of Stress on Top of the Seismogenic Zone of an Erosive Subduction Margin
}

\author{
by Paola Vannucchi, Kohtaro Ujiie, Nicole Stroncik, and
} the IODP Exp. 334 Scientific Party

\begin{abstract}
The Costa Rica Seismogenesis Project (CRISP) is an experiment to understand the processes that control nucleation and seismic rupture of large earthquakes at erosional subduction zones. Integrated Ocean Drililng Program (IODP) Expedition 334 by R/V JOIDES Resolution is the first step toward deep drilling through the aseismic and seismic plate boundary at the Costa Rica subduction zone offshore the Osa Peninsula where the Cocos Ridge is subducting beneath the Caribbean plate. Drilling operations included logging while drilling (LWD) at two slope sites (Sites U1378 and U1379) and coring at three slope sites (Sites U1378-1380) and at one site on the Cocos plate (Site U1381). For the first time the lithology, stratigraphy, and age of the slope and incoming sediments as well as the petrology of the subducting Cocos Ridge have been characterized at this margin. The slope sites recorded a high sediment accumulation rate of $160-1035 \mathrm{~m}$ m.y.-1 possibly caused by on-land uplift triggered by the subduction of the Cocos Ridge. The geochemi-
\end{abstract}

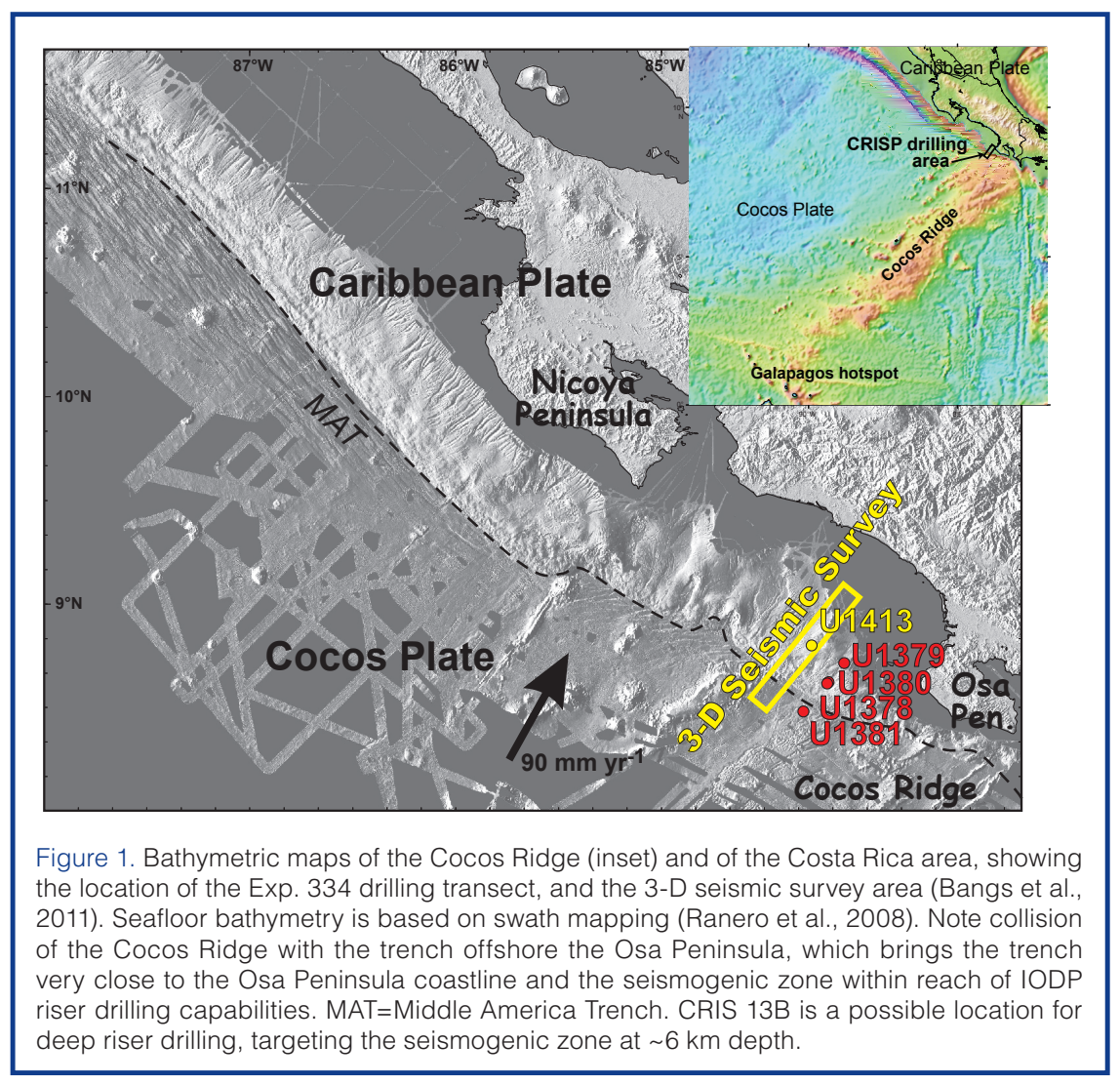

cal data as well as the in situ temperature data obtained at the slope sites suggest that fluids are transported from greater depths. The geochemical profiles at Site U1381 reflect diffusional communication of a fluid with seawater-like chemistry and the igneous basement of the Cocos plate (Solomon et al., 2011; Vannucchi et al., 2012a). The present-day in situ stress orientation determined by borehole breakouts at Site U1378 in the middle slope and Site U1379 in the upper slope shows a marked change in stress state within $\sim 12 \mathrm{~km}$ along the CRISP transect; that may correspond to a change from compression (middle slope) to extension (upper slope).

\section{Introduction and Goals}

Subduction megathrusts are responsible for the largest earthquakes on Earth and are often accompanied by devastating tsunamis. Erosive margins, which occur along at least $50 \%$ of the global subduction zones (Clift and Vannucchi, 2004), can generate magnitude 9.0 earthquakes, as shown by the 2011 Tohoku-Oki earthquake and tsunami, which occurred off the northeast coast of Japan. Typical of erosive convergent margins is the upper plate prov-enance of the material that is present along the megathrust at seismogenic depth. The upper plate material can be anything from crystalline rocks to sediments lithified and deformed in a previous, no longer active accretionary prism.

CRISP is designed to investigate the first-order seismogenic processes common to most faults, such as dynamic weakening processes as thermal pressurization (Wibberley and Shimamoto, 2005) or melt lubrication (Di Toro et al., 2006) and eventually those unique to erosional margins. The Costa Rica Margin is well studied (Fig. 1) and is currently the only known erosional end-member of convergent margins in which the seismogenic zone is realistically within reach of scientific drilling $(\sim 6 \mathrm{~km}$ depth, Ranero et al., 2006). With a fast convergence rate (90 $\mathrm{mm} \mathrm{yr}^{-1}$, DeMets, 2001), abundant seismicity (DeShon et al., 2003), subduction erosion (Ranero and von Huene, 2000; Vannucchi et al., 2001), and change in 
subducting plate relief along strike, the margin offshore southeast Costa Rica offers excellent opportunities to learn the mechanisms of earthquake nucleation and rupture propagation.

CRISP is conceived as a multiple platform drilling project with an initial exploration of the margin through riser-less drilling with the R/V JOIDES Resolution and a successive, deep penetration of the seismogenic portion of the megathrust with the riser drilling technology offered by D/V Chikyu. IODP Exp. 334 was planned as the riserless first phase of CRISP, called CRISP Program A.

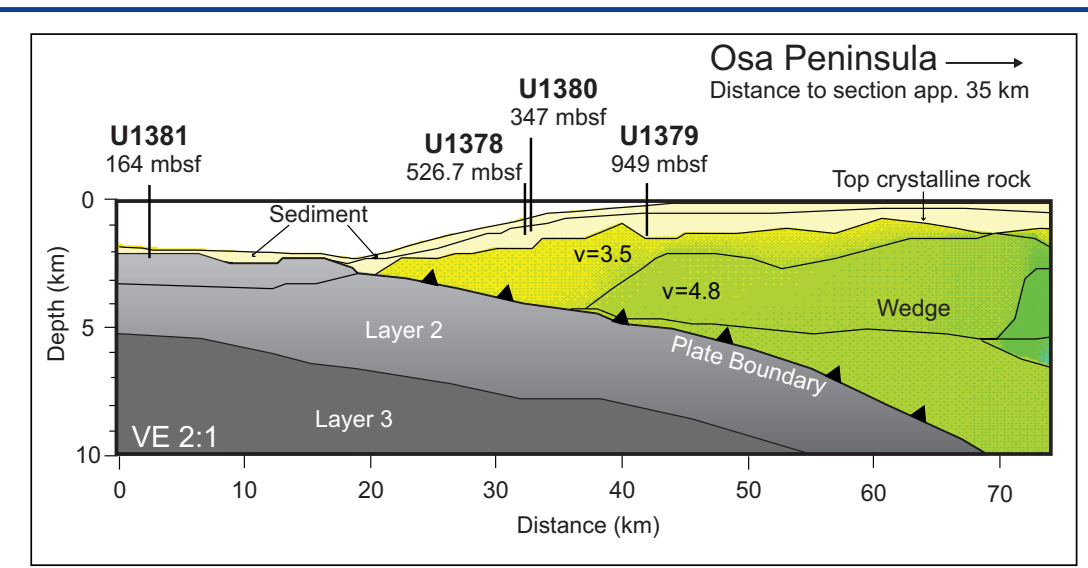

Figure 2. Interpreted wide-angle seismic section from Stavenhagen et al. (1998). Schematic figure through the Osa Peninsula margin showing Sites U1381, U1378, U1380, and U1379. $\mathrm{VE}=$ vertical exaggeration, $\mathrm{V}=\mathrm{P}$-wave velocity $\left(\mathrm{km} \mathrm{s}^{-1}\right)$.
The primary goals of Exp. 334 were as follows:

1. Characterization of lithological, physical, and frictional properties of upper plate material;

2. Estimation of subduction channel thickness and the rate of subsidence caused by subduction erosion;

3. Investigation of the fluid flow system and thermal structure of the erosive margin;

4. Determination of the change in the stress field across the updip limit of the seismogenic zone; and

5. Characterization of the influence of Cocos Ridge subduction on the evolution of the Central America volcanic arc and development of the volcanic arc gap inboard Cocos Ridge.

Tectonic, hydrologic, and physical conditions along this erosive convergent margin were investigated through continuous coring at three slope sites: Sites U1378 and U1380 on the middle slope and Site U1379 on the upper slope, and at one site on the Cocos plate, Site U1381 (Fig. 2). LWD was first conducted at Sites U1378 and U1379 to document the in situ physical properties, stratigraphic and structural features, and stress state of the material to be cored.

\section{Geological Setting and Earlier Work}

The oceanic Cocos plate subducting beneath Costa Rica has been formed at two different spreading centers, the East Pacific Rise (EPR) and the Cocos-Nazca Spreading Center (CNS), and it has been largely influenced by Galapagos hotspot volcanism. The largest feature formed by the passage of the Cocos plate over the Galapagos hotspot is the 2.5-km-high Cocos Ridge (Fig. 1). The oceanic crust beneath the ridge is about $20 \mathrm{~km}$ thick (i.e., three times thicker than normal oceanic crust; Sallares et al., 2003). The influence of Cocos Ridge subduction increases from the Nicoya Peninsula in the northwest, where sills of Galapagos provenance abundantly infiltrate the igneous basement (Kimura et al., 1997; Morris et al., 2003), to the Osa Peninsula in the southeast (Fig. 1).

The CRISP transect is located along the northwest flank of the subducting Cocos Ridge, over a patch of shallow (updip limit $\sim 4-5 \mathrm{~km}$ below the seafloor) seismically active megathrusts. The M6.4 June 2002 thrust earthquake off Caño Island, which occurred at a depth of $\sim 9 \mathrm{~km}$, and its aftershock sequence were located in the CRISP drilling area (Fig. 3; S.L. Bilek, pers. comm., 2003; I. Arroyo, pers. comm., 2009). GPS measurements on land indicated high stress over the subducted Cocos Ridge with most of the plate interface in the seismogenic region essentially fully locked (Dixon, 2003). In contrast, seismic profiles indicate fault geometries (i.e., angles between forethrusts, backthrusts, and the décollement), suggesting low values of plate boundary friction (von Huene et al., 2000, 2003, 2004). Fluids draining from the subducting lower plate are abundant, as indicated by numerous vents (Ranero et al., 2008). Using bottom-simulating reflector (BSR) depths as a proxy for heat flow, temperatures along the megathrust beneath the mid-slope drilling sites were estimated to range between $60^{\circ} \mathrm{C}$ and $90^{\circ} \mathrm{C}$ (Harris et al., 2010a, 2010b).

Drilling and seismic data indicate active and long-lived subduction erosion from Guatemala to Costa Rica (Ranero and von Huene, 2000; Ranero et al., 2000; Vannucchi et al., 2001, 2003, 2004). This interpretation is based on long-term subsidence of the continental slope offshore the Nicoya Peninsula. ODP Leg 170 provided direct evidence of shallow-water sedimentary rocks, now located in $3900 \mathrm{~m}$ water depth on the forearc and marking the slope apronforearc basement unconformity, showing that the margin offshore the Nicoya Peninsula has experienced a net loss of crust since $\sim 16 \mathrm{Ma}$ (Vannucchi et al., 2001).

The forearc basement (i.e., the framework of the upper plate below the shelf/slope sediments) was the main target of IODP Exp. 334 (Fig. 2). The pre-expedition hypothesis 
was that a high amplitude seismic reflector at the base of the well-stratified slope apron marks the unconformity between the forearc basement and the shelf/slope sediment. Drilling through the reflector disproved the pre-expedition hypothesis, as the cored material resulted as still infilling of the forearc basin. The forearc basement in the CRISP area, instead, has been interpreted from seismic profiles (Stavenhagen et al., 1998) to be composed of a middle Eocene-middle Miocene unit of oceanic lithologies accreted to the overriding plate (Vannucchi et al., 2006) very similar to the Osa Mélange. The Osa Mélange, dominated by basalt, radiolarite, and limestone, is the most seaward unit exposed on land close to the CRISP transect. The forearc basement, therefore, was not reached by drilling during Exp. 334 .

On the incoming plate, the irregular topography of the Cocos Ridge has a direct effect on the thickness of its sedimentary cover. In areas of low seafloor topography on the northern flank of the Cocos Ridge, the sediment thickness reaches $200 \mathrm{~m}$; by contrast, only a 100-m-thick sediment cover is found in areas of the northern flank of the ridge with high seafloor topography.

\section{Preliminary Scientific Results}

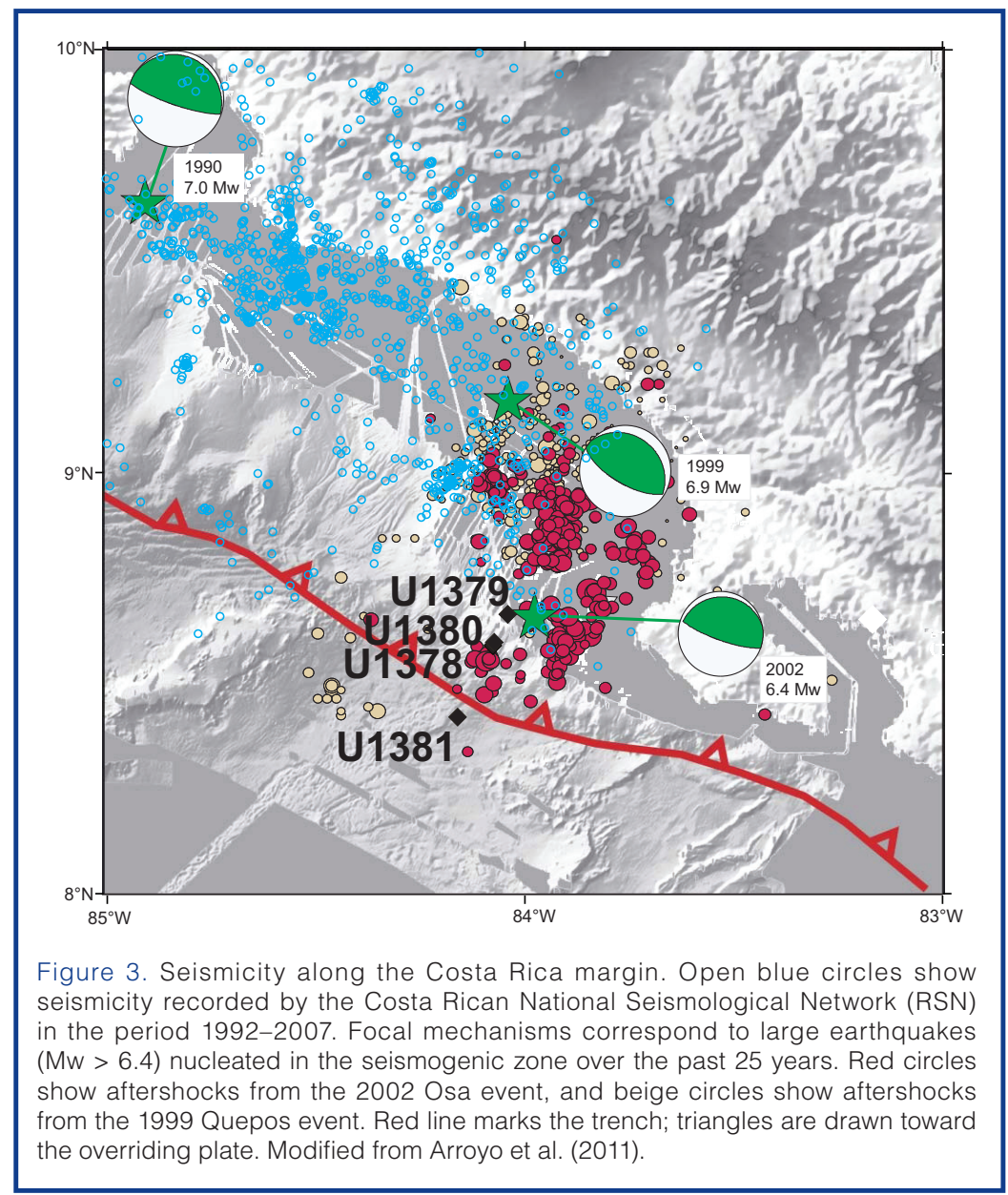

Exp. 334 drilled four sites in four weeks (Fig. 4): one on the Caribbean plate shelf into the upper slope (Site U1379), two into the middle slope (Sites U1378 and U1380), and one on the subducting Cocos Plate (U1381). Site U1381 also represents the first-ever penetration of the Cocos Ridge igneous basement. Acquisition of LWD logs prior to coring was successfully implemented at Sites U1378 and U1379 (Fig. 5).

Slope sediments at Sites U1378-U1380 were retrieved with a $100 \%$ recovery rate. At Site U1379 material marking the acoustic basement was reached below the high amplitude reflector. The recovery rate of this material was $\sim 20 \%$. Unfortunately, at Sites U1378 and U1380 both LWD and coring had to be stopped before reaching the target depth because of deteriorated hole conditions.

In the following paragraphs we summarize the five main accomplishments of IODP Exp. 334.

\section{Estimating the composition, texture, and physical properties of the upper plate material}

In erosive margins the upper plate material hosts the seismogenic portion of the plate boundary. The plate boundary itself is frequently addressed as a subduction channel where deformation is largely concentrated in a relatively thick layer of shearing; fluid driven processes weaken the upper plate and promote upward migration (i.e., toward the upper plate) of the active décollement. Sampling the upper plate material not only provides us with the opportunity to characterize its composition, texture, and physical properties and to conduct structural analysis and laboratory tests, but also with critical information in preparation for the deep riser drilling. The main objective of IODP Exp. 334 was to drill through the forearc sediments and reach the basement below the high amplitude reflector. At the shelf/upper slope Site U1379, located in $127 \mathrm{~m}$ water depth, both cores and LWD logs reached and penetrated below this reflector (Fig. 5b). LWD logs showed a marked increase in density and resistivity at $\sim 892$ meters below seafloor (mbsf). This change in physical properties was initially interpreted as penetration into the upper plate basement. Indeed, successive coring at Site U1379 showed a complex change in lithostratigraphy, going from the turbiditic sandstones with lithic fragments of igneous origin (Unit III) to near-shore sandstones with bioclasts (Unit IV), to a poorly sorted, well-lithified breccia with sandy matrix and igneous, calcareous, and mudstone clasts, to mudstone named Unit V (Fig. 4). The base of Unit IV was interpreted as marking the high amplitude reflector and laying unconformably on Unit V, which formed the acoustic basement at Site U1379. However, subsequent analysis of the cored material showed that we did not reach the forearc basement of the Caribbean plate, but rather an older forearc basin where clasts of basement were dispersed in fine, deepwater sediments. 
A second penetration of the basement was attempted at Site U1378. Hole conditions did not allow reaching deeper than 457 mbsf during logging and 524 mbsf during coring at this site, whereas the expected depth of the top of the basement was $~ 750$ mbsf. Detailed description of the cored sediments revealed the presence of a highly fractured and brecciated zone at 498-520 mbsf, interpreted as a fault zone, which may have caused the encountered drilling problems.

A final attempt to reach the basement was conducted at Site U1380, where the basement was expected to start at $\sim 550$ mbsf. Site U1380 is $\sim 1 \mathrm{~km}$ upslope from site U1378, but the same drilling problems as at Site U1378 were encountered at this site, here at a depth of $482 \mathrm{mbsf}$. Therefore drilling of the middle slope was terminated.

\section{Assess subduction channel thickness and the rate of subduction rrosion}

In an erosive subduction margin, upper plate material is incorporated into the subduction channel because of basal erosion, resulting in subsidence of the upper plate. Thus, to assess the thickness of the subduction channel (Vannucchi et al., 2012b, and references therein) the mass removed from the upper plate has to be estimated, which can be achieved based on subsidence profiles determined from the cored slope sediments.

The first observation acquired from the cores indicates the formation of a well sediment-supplied forearc basin offshore the Osa Peninsula. The preliminary biostratigraphic

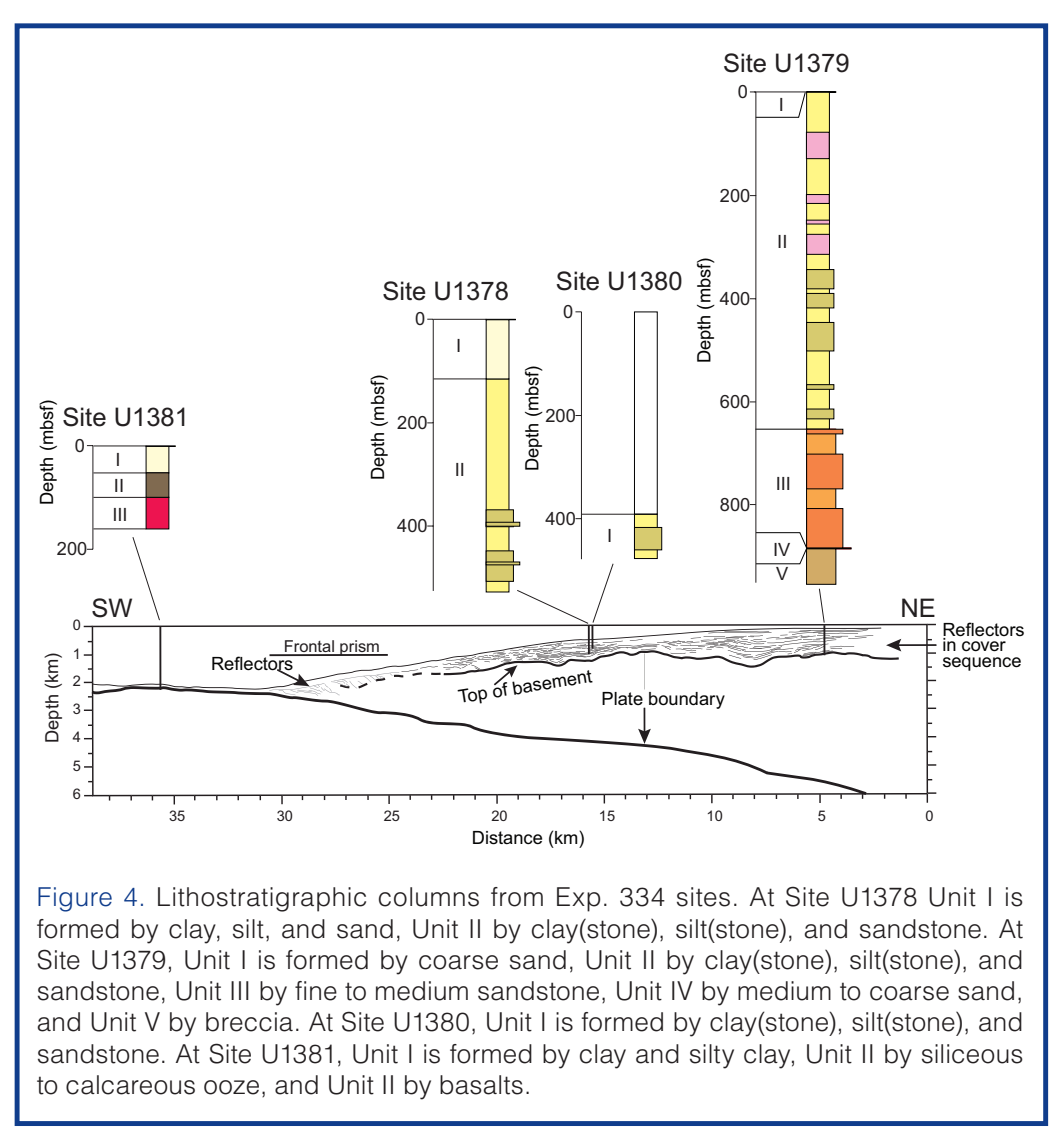

results obtained from the slope sites indicate high sediment accumulation rates in this terrestrially sourced slope sequence, ranging from 236-516 m m.y. ${ }^{-1}$ at Site U1378 in the middle slope to $160-1035 \mathrm{~m} \mathrm{m.y.} .^{-1}$ at Site U1379 in the shelf/upper slope (Fig. 6). In particular, the accumulation rate of the mainly clayey silt/silty clay slope sediments at Site U1379 at $1035 \mathrm{~m}$ m.y.-1 is much higher than that of the middle slope sediments offshore the Nicoya Peninsula (38-99 m m.y. ${ }^{-1}$, Kimura et al., 1997), and twice as high as the sediment accumulation rate along the sediment-rich trench off Muroto in the Nankai Trough (Fig. 5). This remarkably high accumulation rate offshore the Osa Peninsula could have its origin in the on-land uplift triggered by the subduction of the Cocos Ridge. On the other hand, the subduction of such topographic highs likely accelerates the basal erosion of the upper plate causing subsidence. The competition between subsidence and uplift of the forearc offshore the Osa Peninsula is recorded in the sedimentary and biostratigraphic characteristics of the slope sediments. The detailed analyses of sedimentary facies and benthic foraminifer fauna in slope sediments at Sites U1378 and U1379 are keys to estimate the mass removal associated with basal erosion and the thickness of the subduction channel.

\section{Evaluate fluid/rock interaction, the hydrologic system, and the geochemical active within the upper plate}

Fluid flow and fluid pressure in subduction zones can have a profound impact on the shallow thermal structure of the margin, on the content and distribution of fluids within the subducting and upper plates, and on the transfer of elements and isotopes to the ocean volcanic arc and mantle. It is also likely to, directly or indirectly, impact the partitioning of stable slip versus seismogenic slip along the plate boundary (Ranero et al., 2008). Changes in physical and mineralogical properties with depth and associated evolution of fluids in subduction zones may therefore be linked to the transition from aseismic to seismic behavior along the plate boundary (Moore and Saffer, 2001). Fluids advected along fault zones and other permeable horizons in the upper plate may record reactions occurring at greater depths in the subduction zone and can be used to constrain reactions occurring within the seismogenic zone (Vannucchi et al., 2010).

Based on the first results obtained during the shipboard geochemistry program of Exp. 334, two zones with fluid compositions indicative of transport from greater depths could be identified within the upper plate (Vannucchi et al., 2012a). At Site U1381 in the subducting plate, one zone of lateral flow of modified seawater in the igneous basement could be identified. Whereas pore fluids in the uppermost $\sim 50 \mathrm{~m}$ at all sites drilled during Exp. 334 were dominated by reactions associated with the 
cycling of organic carbon, deep fluid flow was also detected at each of the sites cored. This fluid flow overprints the general geochemical profiles that are associated with in situ diagenetic processes such as ion exchange, ongoing microbial metabolic reactions, volcanic ash alteration, and carbonate precipitation and dissolution. At Site U1379, a broad zone from $\sim 600 \mathrm{mbsf}$ to 800 mbsf contains a fluid with low $\mathrm{Cl}$ concentrations and peaks in the concentrations of thermogenic hydrocarbons (ethane, propane, $n$-butane, isobutane). The geothermal gradient at Site U1379 is too low to support the in situ production of thermogenic hydrocarbons or extensive clay dehydration, suggesting a deeper source of the fluid.

At Site U1381, the geochemical profiles below $\sim 50$ mbsf reflect diffusional communication of a fluid with seawater-like chemistry with the igneous basement (Vannucchi et al., 2012a).

\section{Measure the stress field along the CRISP transect}

We estimated present-day in situ stress orientation from borehole breakouts at Site U1378 in the middle slope and Site U1379 in the shelf/upper slope. Borehole breakouts in a vertical hole form in a direction perpendicular to the maximum horizontal principal stress $\left(\sigma_{\text {Hmax }}\right)$ (Zoback et al., 2003). During Exp. 334, borehole breakouts were identified from LWD images of borehole radius and density. In addition, we determined types, orientations, and kinematics of faults from cores.
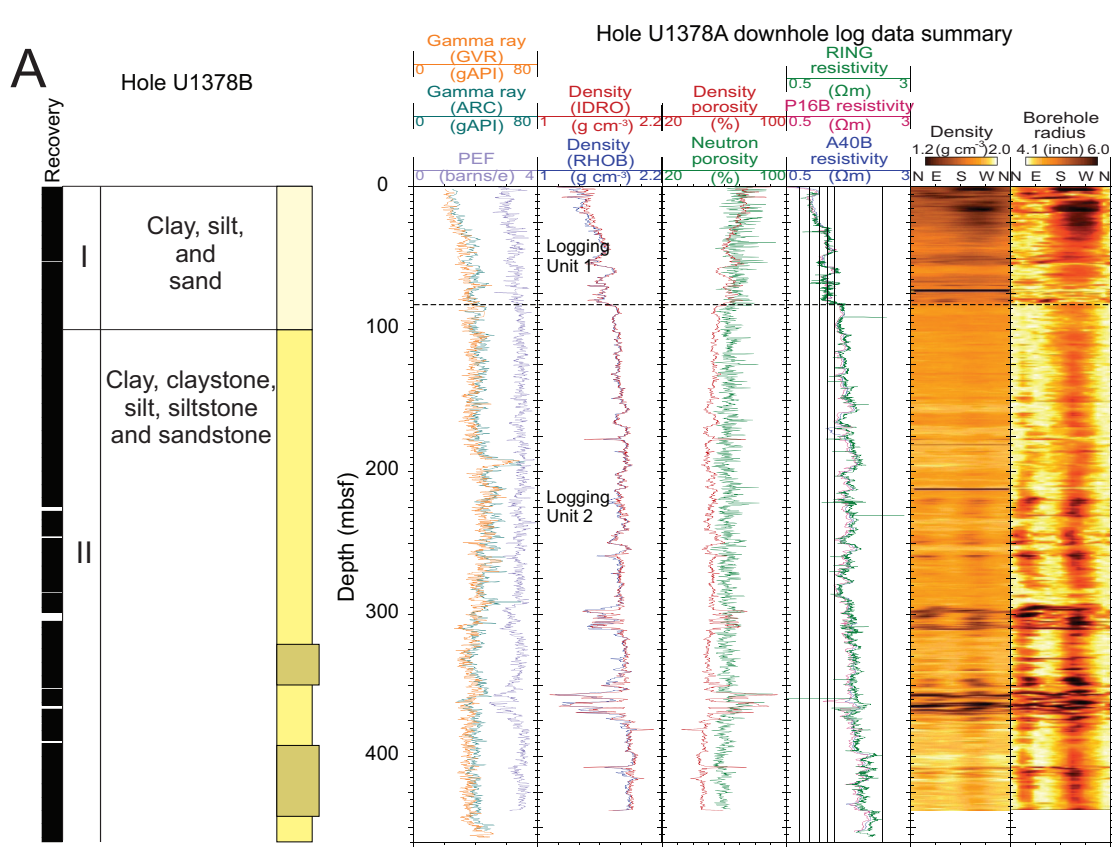

$\mathrm{B}$
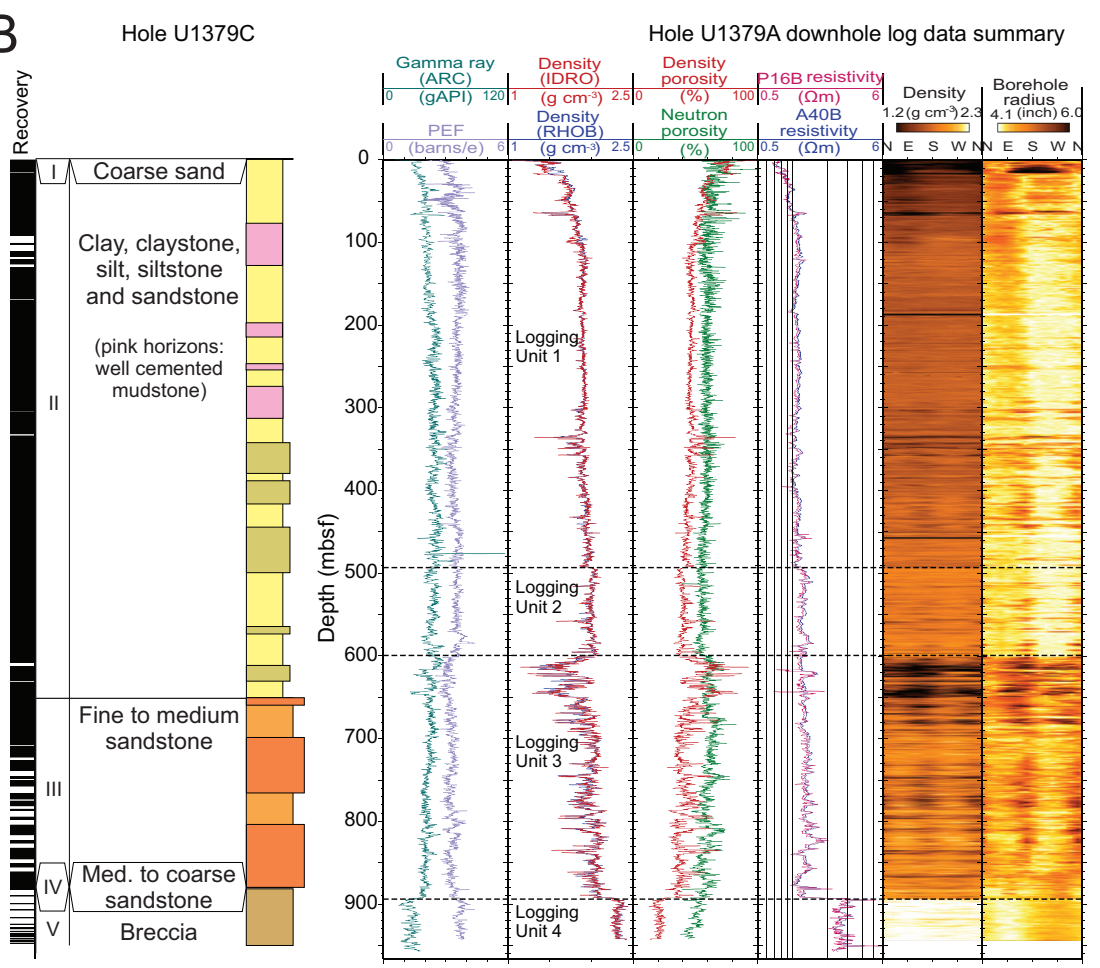

Figure 5. Summary of the lithostratigraphy and LWD measurements. $[A]$ is for Site U1378, [B] for Site 1379C. GVR=geoVISION tool, ARC=arcVISION tool, PEF=photoelectric factor, IDRO=image-derived density (EcoScope tool), RHOB=bulk density, RING=resistivity measured by the ring electrode (geoVISION tool), $\mathrm{P} 16 \mathrm{~B}=$ phase-shift resistivity measured at a 16 -inch source-receiver separation (arcVISION tool), A40B=attenuation resistivity measured at a 40-inch source-receiver separation (arcVISION tool).

The $\sigma_{\mathrm{Hmax}}$ orientation of slope sediments at Site U1379 down to a depth of $850 \mathrm{mbsf}$ is east-northeast/westsouthwest, below which $\sigma_{H \max }$ seems to rotate to north/ south for about $50 \mathrm{~m}$ (Fig. 5). No obvious borehole breakouts appear below about $900 \mathrm{mbsf}$ in the underlying acoustic basement (Fig. 5). Normal faults dominate the cores of the slope sediments at Site U1379 (Fig. 7). The kinematic analyses of the normal faults indicate a vertical maximum principal stress $\left(\sigma_{1}\right)$, an intermediate principal stress $\left(\sigma_{2}\right)$ oriented west-northwest/east-southeast, and a minimum principal stress $\left(\sigma_{3}\right)$ oriented north-northeast/south-southwest (Fig. 7). The $\sigma_{\mathrm{H} \max }$ orientation at Site U1379 for the upper $850 \mathrm{mbsf}$ is consistent with north-northwest/southsoutheast-directed horizontal extension, which is subparallel to the plate motion vector detected by GPS mesasurements northwest of the Osa Peninsula (LaFemina et al., 2009). On the other hand, the $\sigma_{3}$ orientation determined from kinematic analyses of core-scale normal faults is 


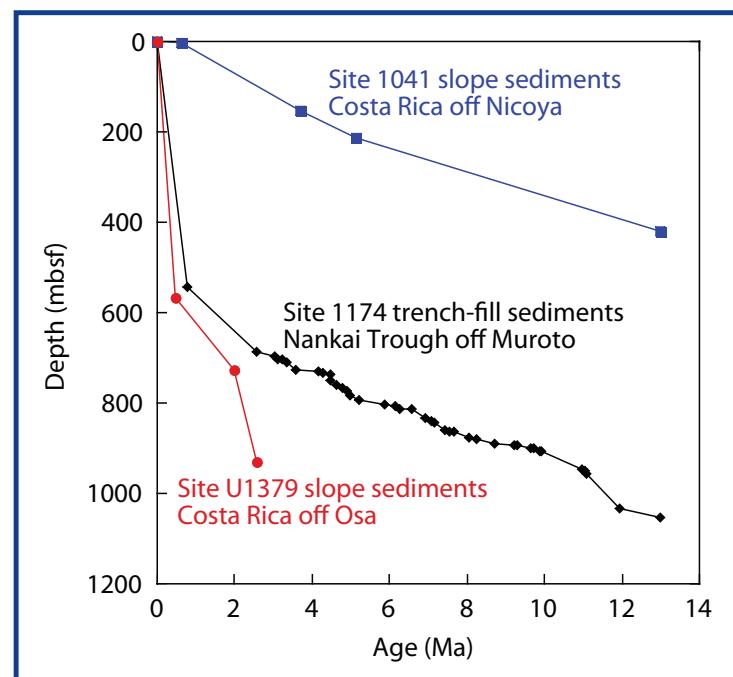

Figure 6. Comparison of sediment accumulation rates calculated from IODP Site U1379, and ODP Sites 1041 and 1174

parallel to the convergence direction between the Cocos and Caribbean plates (DeMets, 2001). Core-scale normal faults record instantaneous stress conditions when the faults are active. Although stress data sets are derived from slope sediments overlying the upper plate basement, trench-normal extension in the upper section of Site U1379 is consistent with extensional faulting in the submarine wedge associated with basal erosion (Ranero and von Huene, 2000).

The in situ stress field configuration seems to be more complex considering the 50-m interval between $850 \mathrm{mbsf}$ and 900 mbsf. Borehole breakouts, in fact, seem to indicate about a $90^{\circ}$ rotation of $\sigma_{\mathrm{H} \text { max }}$ orientation, very similar to the breakout orientation of slope sediments at Site U1378. There, $\sigma_{\text {Hmax }}$ is oriented north-northwest/south-southeast (Fig. 7). At Site U1378 both normal and reverse faults are observed in cores from the slope sediments. The $\sigma_{\text {Hmax }}$ orientation at Site U1378 and possibly in the deeper portion of U1379 is consistent with the north-northwest-directed plate motion vector detected by the GPS measurement northwest of the Osa Peninsula (LaFemina et al., 2009) and is oblique to the convergence direction (north-northeast) between the Cocos and Caribbean plates (DeMets, 2001). The Cocos Ridge is con-sidered to act as a rigid indenter to the Caribbean plate, resulting in a change in plate motion from north-northeast-directed trench-normal motion in southern Costa Rica to trench-parallel motion in central Costa Rica where plate convergence is normal to the trench (LaFemina et al., 2009). North-northwest-oriented $\sigma_{\mathrm{Hmax}}$ at Sites U1378 and U1379 may represent the shortening of the middle slope opposite the northwestern flank of the Cocos Ridge (thrust faulting stress regime), where plate motion likely deviates from trench-normal motion, although strike-slip and/or normal stress states are also possible.
5. Reconstruct the Cocos Ridge subduction: evolution of the Central American volcanic arc and development of the volcanic arc gap inboard Cocos Ridge

Site U1381 sampled the sediments and basalts of the Cocos Ridge, which represents the trace of the Galapagos hotspot on the Cocos plate. Approximately eighty meters of basalts were recovered from below $100 \mathrm{~m}$ of biogenic pelagic sediments consisting mainly of siliceous to calcareous oozes. Investigations are currently being conducted to study the petrogenesis and geochemistry of these basalts as well as fluid/rock interaction processes that may be occurring.

In addition to the igneous rocks cored at Site U1381, approximately 170 tephra layers were retrieved, described, and sampled from the holes cored at the four different sites visited during Exp. 334. Tephra ages range from middle Miocene to the present. Post-cruise analyses of the tephra will shed light on the evolution of the magmatic arc, including the deactivation of the volcanoes located on the presentday location of the Talamanca Cordillera.

\section{Plans for Future Investigations}

Because of an abbreviated operation schedule of IODP Exp. 334, the original CRISP Program A plan was reduced and kept mainly focused on the middle and shelf/upper slope region off the Osa Peninsula. IODP Exp. 344 returned to the Costa Rica margin with the aim to complete CRISP Program 
A (Expedition 344 Scientists, 2013) in preparation of later, deep and riser-supported drilling into the basement, and ultimately through the plate interface in locations of both aseismic and seismogenic fault behavior. A 3-D reflection seismic survey conducted in April 2011 over the Costa Rica margin (Bangs et al., 2011) will provide further information on potential locations for such deep drilling. One potential site, IODP Site U1413, at a water depth of $540 \mathrm{~m}$ and located over the up-dip end of the seismogenic zone has already been identified and cored during Exp. 344 (Fig. 1).

\section{The IODP Expedition 334 Scientific Party}

Alberto Malinverno, Ivonne Arroyo, Udo Barckhausen, Marianne J. Conin, Susan Murr Foley, Michael J. Formolo, Robert N. Harris, Arnauld Heuret, Gary J Huftile, Jun Kameda, Gil Young Kim, Steffen O. Kutterolf, Amanda J. Martino, Gillian A. McCay, Marianne Nuzzo, Ken’ichi Ohkushi, Saneatsu Saito, Peter B. Sak, Evan A. Solomon, Michael Stipp, Marta E. Torres, Akito Tsutsumi, Masaoki Uno, Yoichi Usui, Yatheesh Vadakkeyakath, Yuzuru Yamamoto, Xixi Zhao, Junjiang Zhu and Jenifer Saltman (Education and Outreach)

\section{References}

Arroyo, I. G., Grevemeyer, I., von Huene, R., Husen, S., Ranero, C. R., and Behrmann, J. H., 2011. Interplate seismicity at the CRISP site: The 2002 Osa earthquake sequence. [Paper presented at the American Geophysical Unon Fall 2011 Meeting, San Francisco, 5-9 December 2011]. Abstract T21B-2348.

Bangs, N. L.; McIntosh, K. D.; Silver, E. A.; Ranero, C. R.; Kluesner, J. W.; von Huene, R., Cavanaugh, S. et al., 2011. Preliminary results of the CRISP 3D seismic experiment, offshore Costa Rica. [Paper presented at the American Geophysical Union Fall Meeting, San Francisco, CA, 5-9 December 2011]. Abstract T21B-2341.

Clift, P. D., and Vannucchi, P., 2004. Controls on tectonic accretion versus erosion in subduction zones: Implications for the origin and recycling of the continental crust: Rev. Geophys., 42:RG2001. doi:2010.1029/2003RG000127

DeMets, C., 2001. A new estimate for present-day Cocos-Caribbean plate motion: Implications for slip along the Central American volcanic arc. Geophys. Res. Lett., 28:4043-4046. doi:10.1029/2001GL013518

DeShon, H. R., Schwartz, S. Y., Bilek, S. L., Dorman, L. M., Gonzalez, V., Protti, J. M., Flueh, E. R., and Dixon, T. H., 2003. Seismogenic zone structure of the southern Middle America Trench, Costa Rica. J. Geophys. Res. B Solid Earth, 108:2491. doi:10.1029/2002JB002294

Di Toro, G., Hirose, T. Nielsen, S., Pennacchioni, G., and Shimamoto, T. 2006. Natural and experimental evidence of melt lubrication of faults during earthquakes. Science, 311:647-649. doi: 10.1126/science.1121012

Dixon, T. H., 2003. Relations between seismic coupling and mountain building based on GPS observations in Costa Rica. Geophys.
Res. Abstr., 5:4374.

Expedition 344 Scientists, 2013. Costa Rica Seismogenesis Project, Program A Stage 2 (CRISP-A2): Sampling and quantifying lithologic inputs and fluid inputs and outputs of the seismogenic zone. IODP Prel. Rept., 344. doi:10.2204/iodp. pr.344.2013

Harris, R. N., Grevemeyer, I., Ranero, C. R., Villinger, H., Barckhausen, U., Henke, T., Muller, C., and Neben, S., 2010a. The thermal regime of the Costa Rican convergent margin: 1. Alongstrike variations in heat flow from probe measurements and estimated from bottom-simulating reflectors. Geochem. Geophys. Geosyst., 11:Q12S28.

Harris, R. N., Spinelli, G., Ranero, C. R., Grevemeyer, I., Villinger, H., and Barckhausen, U., 2010b. The thermal regime of the Costa Rican convergent margin: 2. Thermal models of the shallow Middle America Subduction Zone offshore Costa Rica. Geochem. Geophys. Geosyst., 11:Q12S29.

Kimura, G., Silver, E. A., Blum, P., et al., 1997. Proc. ODP, Init. Repts., 170: College Station, TX (Ocean Drilling Program). doi:10.2973/odp.proc.ir.170.1997

LaFemina, P., Dixon, T. H., Govers, R., Norabuena, E., Turner, H., Saballos, A., Mattioli, G., Protti, M., and Strauch, W., 2009. Fore-arc motion and Cocos Ridge collision in Central America. Geochem. Geophys. Geosyst., 10:Q05S14. doi:10.1029/2008GC002181

Moore, J. C., and Saffer, D., 2001. Updip limit of the seismogenic zone beneath the accretionary prism of southwest Japan: An effect of diagenetic to low-grade metamorphic processes and increasing effective. Geology, 29:183-186. doi: 10.1130/0091-7613

Morris, J. D., Villinger, H. W., Klaus, A., et al., 2003. Proc.ODP, Init. Repts., 205: College Station, TX (Ocean Drilling Program), 75 (CD-ROM).

Ranero, C. R., and von Huene, R., 2000. Subduction erosion along the Middle America convergent margin. Nature, 404:748-752. doi: $10.1038 / 35008046$

Ranero, C. R., Grevemeyer, I., Sahling, U., Barckhausen, U., Hensen, C., Wallmann, K., Weinrebe, W., Vannucchi, P., von Huene, R., and McIntosh, K., 2008. The hydrogeological system of erosional convergent margins and its influence on tectonics and interplate seismogenesis. Geochem. Geophys. Geosyst., 9:Q03S04. doi:10.1029/2007GC001679

Ranero, C. R., Marone, C., Bilek., S., Barckhausen, U., Charvis, P., Collot, J-Y, DeShon, H., at al. 2006. CRISP Program B: The transition from stable to unstable slip at erosional convergent plate boundaries. IODP Proposal 537B-Full4

Ranero, C. R., von Huene, R., Flueh, E., Duarte, M., Baca, D., and McIntosh, K., 2000. A cross section of the convergent Pacific margin of Nicaragua. Tectonics, 19:335-357. doi:10.1029/1999TC900045

Sallares, V., Charvis, P., Flueh, E. R., and Bialas, J., 2003. Seismic structure of Cocos and Malpelo Volcanic Ridges and implications for hot spot-ridge interaction. J. Geophys. Res., 108:2564. doi:10.1029/2003JB002431

Solomon, E. A., Torres, M. E., Harris, R. N., Formolo, M., Nuzzo, M., and the Expedition 334 Scientists, 2011. Geochemical constraints on fluid-rock reactions, fluid sources, and flow 
pathways along the CRISP transect; IODP Expedition 334. [Paper presented at the American Geophysical Union Fall Meeting, San Farncisco, CA, 5-9 December 2011] Abstract T14B-06.

Stavenhagen, A. U., Flueh, E. R., Ranero, C. R., McIntosh, K. D., Shipley, T., Leandro, G., Schulze, A., and Dañobeitia, J. J., 1998. Seismic wide-angle investigations in Costa Rica A crustal velocity model from the Pacific to the Caribbean. Zbl. Geol. Paläont., 1:393-408.

Vannucchi, P., Fisher, D. M., Gardner, T. W., and Bier, S., 2006. From seamount accretion to tectonic erosion: Formation of Osa Mélange and the effects of Cocos Ridge subduction in southern Costa Rica. Tectonics, 25:TC2004. doi:10.1029/ 2005TC001855

Vannucchi, P., Galeotti, S., Clift, P. D., Ranero, C., and von Huene, R., 2004. Long-term subduction-erosion along the Middle America Trench. Geology, 32:617-620. doi:10.1130/G20422.1

Vannucchi, P., Ranero, C. R., Galeotti, S., Straub, S. M., Scholl, D. W., and McDougall-Ried, K., 2003. Fast rates of subduction erosion along the Costa Rica Pacific margin: Implications for nonsteady rates of crustal recycling at subduction zones. J. Geophys. Res., 108:2511, doi:10.1029/2002JB002207

Vannucchi, P., Remitti, F., Bettelli, G., Boschi, C., and Dallai, L., 2010. Fluid history related to the early Eocene-middle Miocene convergent system of the Northern Apennines (Italy): Constraints from structural and isotopic studies. J. Geophys. Res., 115:B05405. doi:10.1029/2009JB006590

Vannucchi, P., Sage, F., Morgan, J. P., Remitti, F., and Collot, J. Y., 2012b. Toward a dynamic concept of the subduction channel at erosive convergent margins with implications for interplate material transfer. Geochem. Geophys. Geosyst., 13:Q02003. doi:10.1029/2011GC003846

Vannucchi, P., Scholl, D. W., Meschede, M., and McDougall-Reid, K., 2001. Tectonic erosion and consequent collapse of the Pacific margin of Costa Rica: Combined implications from ODP Leg 170, seismic offshore data, and regional geology of the Nicoya Peninsula. Tectonics, 20:649-668. doi:10.1029/ 2000TC001223

Vannucchi, P., Ujiie, K., Stroncik, N., and the Expedition 334 Scientists, 2012a. Proc. IODP, 334: Washington, DC (Integrated Ocean Drilling Program Management International, Inc.). doi:10.2204/iodp.proc.334.2012

von Huene, R., Alvarado, G., Brown, K., Harris, R., Kinoshita, M., Suyehiro, K., McIntosh, K., et al., 2003. Discussions of ODP Leg 205 and drilling of Middle America seismogenic zone. Eos Trans. AGU, 84:91-92.

von Huene, R., Ranero, C. R., and Vannucchi, P., 2004. Generic model of subduction erosion. Geology, 32:913-916. doi:10.1130/ G20563.1

von Huene, R., Ranero, C. R., Weinrebe, W., and Hinz, K., 2000. Quaternary convergent margin tectonics of Costa Rica, segmentation of the Cocos Plate, and Central American volcanism. Tectonics, 19:314-334. doi:10.1029/1999TC001143

Wibberley, C., and Shimamoto, T., 2005. Earthquake slip weakening and asperities explained by thermal pressurization, Nature, 436:689-692. doi:10.1038/nature03901
Zoback, M. D., Barton, C. A., Brudy, M., Castillo, D. A., Finkbeiner, T., Grollimund, B. R., Moos, D. B., Peska, P., Ward, C. D., and Wiprut, D. J., 2003. Determination of stress orientation and magnitude in deep wells. Int. J. Rock Mech. Min. Sci., 40:1049-1076. doi:10.1016/j.ijrmms.2003.07.001

\section{Authors}

Paola Vannucchi, (Currently) Department of Earth Sciences, Royal Holloway, University of London, Egham, Surrey, TW20 0EX, U.K., e-mail: paola.vannucchi@rhul. ac.uk

Kohtaro Ujiie, Graduate School of Life and Environmental Sciences, University of Tsukuba, 1-1-1 Tennodai, Tsukuba 305-0006, Japan, e-mail: kujiie@geol.tsukuba.ac.jp

Nicole Stroncik, Integrated Ocean Drilling Program, Texas A\&M University, 1000 Discovery Drive, College Station, TX 77845-9547, U.S.A., e-mail: stroncik@iodp.tamu.edu and the IODP Exp. 334 Scientific Party 